\title{
Peeling back the layers: Deconstructing information literacy discourse in higher education
}

\author{
Alison Hicks1 [0000-0002-2124-1730] and Annemaree Lloyd1 [0000-0002-7835-8374] \\ University College, London (UCL), London, UK \\ a.hicks@ucl.ac.uk
}

\begin{abstract}
The discourses of information literacy practice create epistemological assumptions about how the practice should happen, who should be responsible and under what conditions instruction should be given. Analysis of a wide range of documents and texts emerging from the Higher Education (HE) sector suggest that information literacy (IL) is shaped by two competing and incongruent narratives. The outward facing narrative of information literacy (located in information literacy standards and guidelines) positions information literacy as an empowering practice that arms students with the knowledge and skills to battle the complexity of the modern information world. In contrast, the inward facing narrative (located in information literacy texts) positions students as lacking appropriate knowledge, skills and agency. This deficit perception, which has the capacity to influence pedagogical practice, is at odds with constructivist and action-oriented views that are espoused within information literacy instructional pedagogy. This presentation represents the first paper in a research programme that interrogates the epistemological premises and discourses of information literacy within HE.
\end{abstract}

Keywords: Information literacy, Positioning theory, Discourse analysis

\section{$1 \quad$ Introduction}

Drawing from an ongoing analysis of discourses and practices that shape information literacy in higher education (ILiHE), this paper presents an epistemological account of the discourse of information literacy. The intention of this research is to interrogate the institutional approach to the practice and delivery of information literacy by peeling back the layers of the broader information literacy narrative. The findings presented here are part of a larger programme of research that is exploring how librarians, students and the practice of IL are positioned within the higher education sector.

The questions that guide this section of the ILiHE project are:

- How does the discourse of ILiHE position information literacy in professional guidelines, models and texts?

- How does the discourse of ILiHE position students as learners? 
An epistemological account of information literacy within the higher education (HE) sector leads us, as researchers, to question information literacy practice according to the discourses (how reality can be known/ what knowledges and ways of knowing are legitimised and accepted) that shape and situate it (the relationship between the knower and what is known/ how information literacy happens in HE); its characteristics (the principles, assumptions that guide the process of knowing and action), and the possibility for the practice to be shared and repeated by others in the same HE setting.

The emerging analysis of ILiHE suggests that information literacy is characterised by outward-facing statements (located in information literacy standards and guidelines) that position IL as an empowering practice, with inward-facing articulations (located in information literacy texts) positioning students as deficient and unable to successfully engage with the practice to inform their learning. This leads us to assert that disparities between these outward and inward-facing narratives form one of the most fundamental and problematic failures of ILiHE, because the starting point of the narrative of ILiHE and the operationalisation of the practice becomes a deficit approach rather than an approach that focuses on the strengths and knowledges that diverse student cohorts bring to the construction of the ILiHE information landscapes. We also propose that this ongoing marginalisation may, in part, contribute to students' resistance to engage with these ideas.

We further suggest that while much research has been conducted into the operationalisation of ILiHE, the field cannot progress until the foundational tensions between these two faces of practice has been resolved. We argue that the inward IL narrative requires re-examination to focus on the strengths of IL practice and its capacity to accommodate diversity rather than to promote deficiency while the outward narrative of IL must be reframed to highlight more of the complex and messy dimensions of IL practice. Failing to acknowledge and address these tensions creates the risk of minimising the sustainable aspects of information literacy as a core practice of student learning.

\section{$2 \quad$ Literature Review}

The last decade has seen the emergence of a second wave of institutional information literacy models. Starting with the UK's ANCIL model, which was released in 2011 [1], and the Metaliteracy model, which was created in the US by Jacobson and Mackey in 2013 [2], the Association of College and Research Libraries (ACRL) released the Framework for Information Literacy in Higher Education in 2016 [3], its first major update of information literacy since 2000 [4]. These new guidelines, which built on long-standing critiques of traditional information literacy standards and documents [5, $6,7]$, aimed to update information literacy for the challenges posed by dynamic and changing information environments. In further focusing attention on information literacy concepts rather than skills and competencies, they marked a significant turn for a field that has tended to emphasise positivist methods of instruction and assessment.

The release of this second wave of documents has not been without controversy [8]. Commentators questioned what was lost through the profession's explicit move away 
from standard practice [9], and there was a sudden resurgence of interest in the standards-based VALUE rubric for information literacy, which was published by the Association of American Universities and Colleges in 2013 [10]. Unease with the dramatic change in focus further catalysed the publication of a number of texts that were designed to help librarians translate these more flexible institutional models into practice (see Appendix A). However, by and large, institutional backing for these documents, coupled with practitioners' espousal of problem-based learning [11] and the flipped classroom [12], amongst other initiatives, marks a growing acceptance of constructivist theories of learning within information literacy teaching research and practice.

These developments have, nonetheless, failed to translate into a broad examination of the practice of information literacy in higher education as it is represented by institutional and other core guiding documents. While Martin [13] scoped four different UK models of information literacy, her work pre-dated the emergence of recent US models of practice. Furthermore, whilst a number of initial small-scale critiques of the ACRL Framework have been published [14, 15], there has been little critical exploration of other prominent models of practice or a sustained exploration of the ideas and principles that are presented through these modernising narratives. These oversights provide an important justification for our programme of study.

\section{$3 \quad$ Methodology}

The overall aim of the ILiHE project is to interrogate and unpack the discourses and practices of information literacy in Higher Education as they relate to students and librarians. For the first stage of the project, a discourse analytical approach was employed to identify the discourses which surround and bind institutional narratives of information literacy within higher education. Texts that were analysed included preambles to the five major English-language information literacy models that have been published since 2010 as well as introductions to books that specifically explore these models (see Appendix A). Book introductions and preambles to institutional models were selected for the framing work that they do to position and contextualise information literacy. This approach also enabled us to carry out an in-depth study of the institutional narratives of information literacy that, as professional documents, serve to both codify and sanction teaching librarian practices. Academic articles were excluded from this sample because of their typical focus on classroom practice and the tendency to avoid framing major information literacy concepts. While the exclusion of empirical and critical articles is a limitation of this study, the focus on institutional narratives provides a useful preliminary way to untangle and draw attention to competing perspectives and expectations within information literacy teaching practices. 


\subsection{Discursive approach and positioning theory}

Discourse is conceptualized in this paper as a complex network of relationships that wind between and entangle people, texts and ideas, leading them to enact practices within agreed boundaries. A discourse analytical approach emphasises social construction of reality and acknowledges the multiplicity of this construction. In the context of information literacy discourse, Lloyd [6] has argued that information literacy is composed of different contexts, different concepts and different truths and that the discourses of higher education that influence the practice and practising of information literacy do not accommodate informal learning, non-textual sources of information or the diversity of learning approaches that students bring to their information practices in the higher education sector. In effect, the discourse community that supports ILiHE creates tensions for students who are not privy to how or why the practice is operationalised in this context, in terms of what knowledges are accepted and which ways of knowing are validated [16, 17, 18].

Information literacy is a practice that is socially enacted [19], and in this study, positioning theory is used as a framework that will allow us to describe how discourses of ILiHE construct and position the performativity of students to create a specific type of interaction and way of doing $I L$ within higher education. Positioning theory has been applied within LIS to studies of mature-aged students and academic information behaviours [20] and physician-patient interaction [21]. We also draw upon other fields where positioning theory has been applied [22, 23, 24, 25].

Positioning theory is located within a constructivist framework and can be useful in understanding the interactional relationship between actors and the discursive texts related to their practices. Moghaddam and Harré [24, p.2] describe positioning theory as "how people use words (and discourse of all types) to locate themselves and others." Positioning can consequently be seen as a productive process that involves the social construction of particular individuals and groups as "culturally imagined types" [22, p.130]. In further asserting that "it is with words that we ascribe rights and claim them for ourselves and place duties on others," Moghaddam and Harré [24, p.3] also signal the moral codes that govern these narratives as well as the ways in which positioning serves as an "intelligible map" [25, p.232] for interaction. In the present research, we aim to illuminate how the discursive texts of ILiHE position both information literacy and learners. As Slocum-Bradley [26, p.81] points out, it is only by understanding "how we construct social reality, we can construct more consciously to sustain norms that promote the ends we profess to desire."

\section{$4 \quad$ Findings and analysis}

Preliminary analysis of book introductions and the preambles of institutional models of information literacy practice suggests the emergence of two distinct narratives. The overall outward-facing narrative positions ILiHE in terms of empowerment and authority over complex, messy, volatile and often fragile information environments. This narrative is in contrast to the inward-facing discourse, which positions students in 
terms of their deficiencies within the discursive framework of higher education. Both discourses act to enable and constrain information literacy practice.

\subsection{How is IL positioned as a practice in HE?}

In the texts and the institutional preambles that were investigated in this study, the discourse of information literacy is described as both practised and agile. Practised information literacy references statements about the assumed generic and timeless aspects of information literacy, which supports the capacity for lifelong learning. This understanding situates information literacy as a set of "core" [27, p.3], "foundational" [3, p.2] or "basic" ideas [28, p.viii] that are mastered progressively [29, p.6; 10, p.1] and form the "foundation of autonomous learning" [1, p.6]. The agile theme establishes the discourse in terms of transferability of skills, the transformative nature of the practice and the capacity to develop reflexivity, openness (to perspectives) and critical thinking. In this theme, information literacy is positioned as "flexible" [3, p. $2 ; 1$, p.4] and not "something learned once and for all" [30, p.xv] as well as "cyclical" [28, p.3] and collaborative $[3$, p. $3 ; 1$, p. $4 ; 31$, p.xv].

While there is a certain tension between these themes, they feed into an overarching discourse of information literacy as "empowerment" or the idea that information literacy will 'empower' learners with the skills or understandings that they need to make informed choices in their current and future endeavours. The themes of practised and agile also act to authorise a specific epistemology (ways of knowing) and knowledge claim, which establishes the contextual foundations of the practice by which students' practising is evaluated.

\subsection{How are learners in HE positioned by the IL discourse?}

In contrast, book introductions reveal that the discourse surrounding student's engagement with information literacy instruction affords learners a social position that emphasises their lack of capacity to learn the information skills associated with the practice. Within this narrative, students are positioned as struggling under the weight of their deficit, which variously positions learners as overwhelmed, passive and uncritical and, in some instances, as plagiarisers.

Learners are positioned as overwhelmed when they are perceived to be unable to cope with an "oversaturated information ecosystem" [31, p.xix] that drowns us in information [32]:

"students need to learn how to deal with the ocean of information that surrounds them" [29, p.10]

Within this framing, information overload is viewed as constraining the ability of students to action their learning, creating the conditions which produce passive students who are unmotivated, lacking in persistence and dependent upon others. Learners are positioned as unmotivated when they are seen to devalue information literacy ideals: 
"someone might be aware that they should carefully evaluate the information they find... yet not care enough to actually do it" [32]

A perceived tendency to give up too easily means that students are similarly positioned as lacking in persistence and patience in their research endeavours:

"they need to be persistent in the search for information" [29, p.10]

Students' passivity subsequently positions them as uncritical of sources or actions of others. Within this theme, the students' lack of agility creates a narrative that suggests inflexibility:

"this process requires the researcher to be flexible... and to keep an open mind" [29, p.9]

Students' lack of criticality further positions them as ignorant of the skills and knowledge that they will need to be successful within today's information environments, which is often portrayed through metaphors that emphasise students' lack of voice:

"before an encounter with a threshold concept, the novice is in a blissful state of ignorance" [28, p.3]

More commonly, students are positioned as being unable to understand variation or nuances within information environments:

"It means... not just reverting to long-standing habits only because they are familiar" [32]

"Students tend to see all information sources as equal unless instructed otherwise" [29, p.7]

These issues are exacerbated by students' feelings of overconfidence [33, p.10].

The discourse also characterises students as plagiarisers who lack the capacity to understand the ethical obligations of academic practice. Within this framing, students are positioned as disrespectful of others' intellectual property as well as liable to make irresponsible decisions:

"ethical use of information is a concept that students struggle to understand" $[29$, p.7]

"[information literacy instruction] is... crucial for their development as informed and responsible citizens" [34, p.xv] 


\section{Discussion}

The discourse of information literacy in the higher education sector is composed of both outward-facing and inward-facing narratives. The outward-facing discourse of information literacy positions the practice as empowering learners by facilitating a critically reflexive engagement with information. Against this discourse is the inward discourse, which positions higher education students as lacking the capacity to develop strategies to inform their learning and meet the rules of academic practices.

The difference between these narratives is striking but not unexpected. Deficiency could be interpreted as an important rationale for information literacy instruction, which empowers the learner to unlock their potential and make more informed and healthy decisions. Within this framing, empowerment is positioned as a "self-evident good" [35, p.53] that enables individuals (or communities) to exercise power in the determination of their everyday life [36].

However, when we position students as deficient, we retreat from the idea that information literacy empowers learners to control their lives. Instead, a narrative that centres upon a lack of ability subtly reframes empowerment in terms of top-down behaviour modification by establishing and holding learners accountable to specific activities and indicators of expertise. Establishing a "fundamental contrast between those who know and those who are ignorant, between the morally superior and the morally inferior" [37], the emphasis on expert awareness further reinforces the illusion of empowerment by drawing learners into "participating in processes and decisions over which they have little meaningful control" [35, p.58].

Within the context of this study, these ideas suggest that the narratives of empowerment and deficiency are politicised rather than neutral. This leads to further questions about whom or what is empowered, under what conditions or circumstances deficiency is evaluated, and which discourses prevail [19, 38]. Responding to these questions forms the basis of future work by the authors.

\section{Conclusion}

In previous research, Lloyd [6, p.87] argued that:

The current dominant paradigm of information literacy... produces a deficit model of information literacy which does not take into account the importance of informal learning or other sources of information which are accessed through communica -tion or action. This reduces the power of information literacy and the way in which information education is undertaken by students and undergraduates.

Almost fifteen years on from this statement and despite the wider adoption of constructivist models of education, there is little evidence present in the texts reviewed as part of this analysis to suggest that the practising of ILiHE and the narrative that influences these practises has altered. However, for the practice of information literacy to be sustainable in the HE context, our analysis suggests that authors (of texts, 
preambles, standards and guidelines) and researchers working in this sector should focus more closely on the ways in which these statements and documents position both IL and students. Future research should continue to explore these ideas as well as to extend this study by examining, for example, how librarians as well as students and information literacy are positioned within institutional narratives.

\section{References}

1. Secker, J., Coonan, E.: A New Curriculum for Information Literacy: Curriculum and Supporting Documents. https://newcurriculum.wordpress.com/project-reports-and-outputs/ , last accessed 2019/8/29.

2. Jacobson, T.E., Mackey, T.P.: Proposing a metaliteracy model to redefine information literacy. Communications in Information Literacy, 7(2), 84-91 (2013).

3. ACRL (Association of College and Research Libraries). Framework for information literacy for higher education. http://www.ala.org/acrl/standards/ilframework, last accessed 2019/8/29

4. ACRL (Association of College and Research Libraries). Information literacy competency standards for higher education. www.ala.org/ala/acrl/acrlstandards/standards.pdf, last accessed 2019/8/29.

5. Bruce, C.: The seven faces of information literacy. Adelaide: Auslib Press (1997).

6. Lloyd, A.: Information literacy: different contexts, different concepts, different truths? Journal of Librarianship and Information Science, 37(2), 82-88 (2005).

7. Tuominen, K., Savolainen, R., Talja, S.: Information literacy as a sociotechnical practice. Library Quarterly, 75(3), 329-345 (2005).

8. Bombaro, C.: The framework is elitist. Reference Services Review, 44(4), 552-563, 2016.

9. Drabinski, E., Sitar, M.: What standards do and what they don't. In: McElroy, K. Pagowsky, N. (eds.), Critical Pedagogy Handbook. Chicago: Neal-Schuman (2016).

10. AACU (Association of American Colleges and Universities). Information literacy VALUE rubric. http://www.aacu.org/value/rubrics/information- literacy , last accessed 2019/8/29.

11. Smith Macklin, A.: Integrating information literacy using problem-based learning. Reference Services Review, 29(4), 306-314 (2001).

12. Arnold-Garza, S.: The flipped classroom teaching model and its use for information literacy instruction. Communications in Information Literacy 8(1), 7-22 (2014).

13. Martin, J.: Refreshing information literacy: Learning from recent British information literacy models. Communications in Information Literacy, 7(2) 115-127 (2013).

14. Morgan, P. K.: Pausing at the threshold. portal: Libraries and the Academy, 15(1), 183-195 (2015).

15. Wilkinson, L. (2014). The problem with threshold concepts. Sense and Reference. https://senseandreference.wordpress.com/2014/06/19/the-problem-with-thresholdconcepts/, last accessed 2019/8/29.

16. Burkholder, J. M.: Interpreting the conventions of scholarship: Rhetorical implications of the ACRL Framework. portal: Libraries and the Academy, 19(2), 295-314 (2019).

17. Elmborg, J.: Critical information literacy: Implications for instructional practice. The Journal of Academic Librarianship, 32(2), 192-199 (2006).

18. Kapitzke, C.: (In)formation literacy: a positivist epistemology and a politics of (out)formation. Educational Theory, 53(1), 37-53 (2003). 
19. Lloyd, A.: Information literacy as a socially enacted practice: Sensitising themes for an emerging perspective of people-in-practice. Journal of Documentation, 68(6), 772-783 (2012).

20. Given, L.: Discursive constructions in the university context: Social positioning theory and mature undergraduates' information behaviours. The New Review of Information 3, 127 142 (2002).

21. McKenzie, P.: Positioning theory and the negotiation of information needs in a clinical midwifery setting. Journal of the American Society for Information Science and Technology, 55(8), 685-694 (2004).

22. Holland, D., Leander, K.: Ethnographic studies of positioning and subjectivity: An introduction. Ethos, 32(2), 127-139 (2004).

23. McVee, M., Silvestri, K., Barrett, N., Haq, K.: Positioning Theory. In Alvermann, D., Unrau, N., Sailors, M., Ruddell, R., (eds.), Theoretical models and processes of literacy. New York, NY: Routledge (2019).

24. Moghaddam, F., Harré, R.: Words, conflicts and political processes. In Moghaddam, F., Harré, R., (eds.), Words of conflict, words of war: How the language we use in political processes sparks fighting. Santa Barbara, CA: Praeger (2010).

25. Tirado, F., Gálvez, A.: Positioning theory and discourse analysis: Some tools for social interaction analysis. Historical Social Research/Historische Sozialforschung 33(1), 224-251 (2008).

26. Slocum-Bradley, N.: The positioning diamond: A trans-disciplinary framework for discourse analysis. Journal for the Theory of Social Behaviour, 40(1), 79-107 (2010).

27. Bravender, P., McClure, H., Schaub, G.: Teaching information literacy threshold concepts: Lesson plans for librarians. Chicago: Neal-Schuman (2015).

28. Godbey, S., Wainscott, S., Goodman, X.: Disciplinary applications of information literacy threshold concepts. Chicago: Neal-Schuman (2017).

29. Burkhardt, J. M.: Teaching information literacy reframed: 50+ framework-based exercises for creating information-literate learners. Chicago: Neal-Schuman (2017).

30. Jacobson, T. E., Mackey, T. P.: Metaliteracy in practice. Chicago: Neal-Schuman (2016).

31. Harmeyer, D., Baskin, J. J.: Implementing the information literacy framework: A practical guide for librarians. Lanham: Rowman \& Littlefield (2018).

32. Hosier, A., Bullis, D., Bernnard, D., Vobish, G., Holden, I., Pitera, J., Loney, T., Jacobson, T.: The Information literacy user's guide: An open, online text book. https://textbooks.opensuny.org/the-information-literacy-users-guide-an-open-onlinetextbook/, last accessed 2019/8/29.

33. Mackey, T. P., Jacobson, T. E.: Metaliteracy: Reinventing information literacy to empower learners. London: Facet Publishing (2014).

34. Jacobson, T.: Foreword. In Harmeyer, D., Baskin, J.J. (eds.), Implementing the Information literacy framework: A practical guide for librarians. Lanham: Rowman \& Littlefield (2018).

35. McLaughlin, K.: Empowerment: A critique. Abingdon, Oxon: Routledge (2016).

36. Adams, R.: Empowerment, participation and social work. New York: Palgrave Macmillan (2008).

37. Furedi, F. I don't want to have my awareness raised, thanks. http://www.frankfuredi.com/newsite/article/i_dont_want_to_have_my_awareness_raised_t hanks, last accessed 2019/8/29.

38. Walton, G., Cleland, J.: Information literacy: empowerment or reproduction in practice? A discourse analysis approach. Journal of Documentation, 73(4), 582-594 (2017). 


\section{Appendix A}

\section{Information literacy models}

- A new curriculum for information literacy (ANCIL) (Secker \& Coonan, 2011)

- Framework for information literacy for higher education (ACRL, 2016)

- Metaliteracy (Jacobson \& Mackey, 2014)

- Seven pillars of information literacy (SCONUL, 2011)

- VALUE rubric (AACU, 2013)

\section{Books}

- Metaliteracy

- Jacobson, T. E., Mackey, T. P.: Metaliterate learning for the post-truth world. Chicago: Neal-Schuman (2019).

- Jacobson, T. E., Mackey, T. P.: Metaliteracy in practice. Chicago: Neal-Schuman (2016).

- Mackey, T. P., Jacobson, T. E.: Metaliteracy: Reinventing information literacy to empower learners. London: Facet Publishing (2014).

- Framework

- Bravender, P., McClure, H., Schaub, G.: Teaching information literacy threshold concepts: Lesson plans for librarians. Chicago: ACRL (2015).

- Burkhardt, J. M.: Teaching information literacy reframed: 50+ framework-based exercises for creating information-literate learners. Chicago: Neal-Schuman (2017).

- Godbey, S., Wainscott, S., Goodman, X.: Disciplinary applications of information literacy threshold concepts. Chicago: Neal-Schuman (2017).

- Harmeyer, D., Baskin, J. J.: Implementing the information literacy framework: A practical guide for librarians. Lanham: Rowman \& Littlefield (2018).

- Jacobson, T.: Foreword. In Harmeyer, D., Baskin, J.J. (eds.), Implementing the information literacy framework: A practical guide for librarians, Lanham: Rowman \& Littlefield (2018).

- McClure, R.: Rewired: Research-writing partnerships in a frameworks state of mind. Chicago: Neal-Schuman (2016).

- McClure, R., Purdy, J. P.: The future scholar: Researching and teaching the frameworks for writing and information literacy. Medford, NJ: ASIST (2016).

- Oberlies, M. K., Mattson, J. L.: Framing information literacy: Teaching grounded in theory, pedagogy, and practice. Chicago: Neal-Schuman (2018).

- Seven Pillars/Metaliteracy

- Hosier, A., Bullis, D., Bernnard, D., Vobish, G., Holden, I., Pitera, J., Loney, T., Jacobson, T.: The Information literacy user's guide: An open, online textbook. https://textbooks.opensuny.org/the-information-literacy-users-guide-an-openonline-textbook/, last accessed 2019/8/29.

- ANCIL 
- Coonan, E., Secker, J.: Rethinking information literacy: A practical framework for supporting learning. London: Facet (2013). 